\title{
Gender Pay Gap in the Czech Information and Communication Technology Professionals
}

\author{
Lea NEDOMOVA, Milos MARYSKA and Petr DOUCEK* \\ Prague University of Economics and Business, Prague, Czech Republic; nedomova@vse.cz; \\ milos.maryska@vse.cz; doucek@vse.cz \\ * Corresponding author: doucek@vse.cz
}

\begin{abstract}
The policy to ensure an equal pay for equal work is consistently applied neither in all EU Member States nor in all sectors of the economy. This article analyzes the gap in average gross earnings between women and men in the Czech Republic working in two groups of ICT Professionals (ICT Specialists - CZ_ISCO 25, ICT Technicians - CZ_ISCO 35). We analyzed wage data obtained from Trexima, a.s. for the time period of 2008-2019. The resulting data are adjusted for inflation and converted to the 2008 base as well as converted to EUR, using the average exchange rate of the given year. We analyzed the data for each group by age and achieved education. Overall, we can say that the gender pay gap among ICT Professionals is decreasing, although this decrease is smaller than that in the entire Czech economy. In terms of the gender pay gap, the group under 30 has the minimal gender pay gap and so does the category of ICT Technicians during several years.
\end{abstract}

Keywords: gender pay gap; ICT; gender aspects in ICT; average wage

JEL Classification L63; J16

\section{Introduction}

The International Labor Organization declared the "Equal Renumeration Convention" on an equal pay for equal work in 1951, i.e. almost 70 years ago (Whitehouse \& Smith, 2020). Since then, all world's economies have tried, less or more successfully, to fulfill this declaration. There are studies in all sectors of the economy and in virtually all countries in the world that show inequality in pay for equal work. Usually, this inequality is based on the gender of the worker. As a rule, men are paid more for the same work than women.

\section{State of Art}

Inequality in pay for the same work is a frequently analyzed issue in the entire developed world. There are many studies focusing on this issue in the United States (e.g. Duffin, 2020) and in the European Union. Some studies and articles are sector-oriented (e.g. a pay gap among physicians - Ganguli et al., 2020; Cohen et al., 2020), other studies focus on this problem in the entire economy, such as Peters, Drobe, and Abendroth (2020); Maldonado (2020) or analyze earnings in the entire EU (Langmeeser, Orlowski, \&Rusek, 2020). The study Bergmann, Scheele, and Sorger (2019) analyzes the gender pay gap in different sectors and compares the situation in two very close European countries - Austria and Germany. As to comparable studies in Slovakia, we can mention, e.g. Mitková (2018), where the author 
analyzes the gender pay gap between men and women working in public and private sectors. The ICT sector gender pay gap in Poland is analyzed in Gomolka (2018).

The Czech Republic is no exception; this topic is often analyzed there as well. The Faculty of Business Administration and the Faculty of Informatics and Statistics of the University of Economics in Prague have been focusing on this issue for a long time. Vltavská et al., (2019) analyze the gender pay gap in student earnings and in starting salaries and e.g. article (Forman, 2019) focuses on inequality in pay in the public administration. This article compares data from 2018 from individual ministries of the Czech Republic and concludes that a gender pay gap exists at the central offices of the Czech Republic as well. For instance, elaborations (Marek \& Doucek, 2016; Bílková, 2017) analyze the size and changes in the gender pay gap in the Czech economy. Not too many studies tackle the gender pay gap among ICT Professionals in the Czech economy; however, this issue has been analyzed by a group of employees of the Faculty of Informatics and Statistics of the University of Economics for a long time now, e.g. in (Marek \& Doucek, 2018; Nedomova, Maryska, \& Doucek, 2017; Nedomova \& Doucek, 2015; Marek, Doucek, \& Nedomova, 2018).

The gender pay gap is also examined by Eurostat that every two years publishes information about its trend. The results from 2018 are provided in Figure 1.

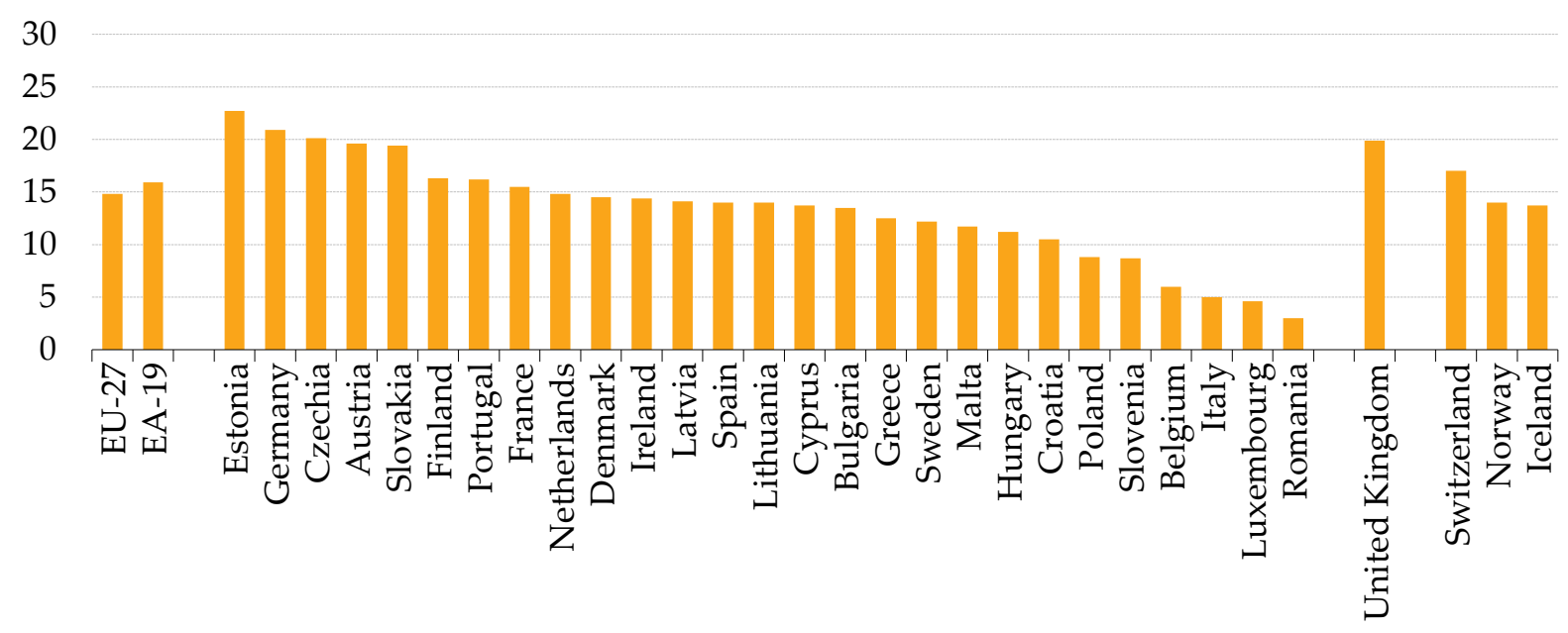

Figure 1. Gender pay gap in average wages in 2018 in EU Member States. Eurostat (2020)

Figure 1 shows that based on Eurostat's data, the Czech Republic is one of the countries with the biggest gender pay gap in the entire European Union - 21.8\%. Only Estonia has a bigger gender pay gap than the Czech Republic - 25.3\%, while the European Union's average is "only" $16.2 \%$. In their study (Boll \& Lagemann, 2014), they try to explain the cause of this gap in individual EU Member States and conclude that the gap in the Czech Republic stems from the economic sector - work description, age and education; however, the biggest part of the gap is referred to in their study as "Unexplained Gap" for which the authors did not find any explanation during their research. We will add to this static view from 2018 (the published data are from 2018) the data in Figure 2, where we show the trend of the gender pay gap in the Czech economy during 2008-2018. 


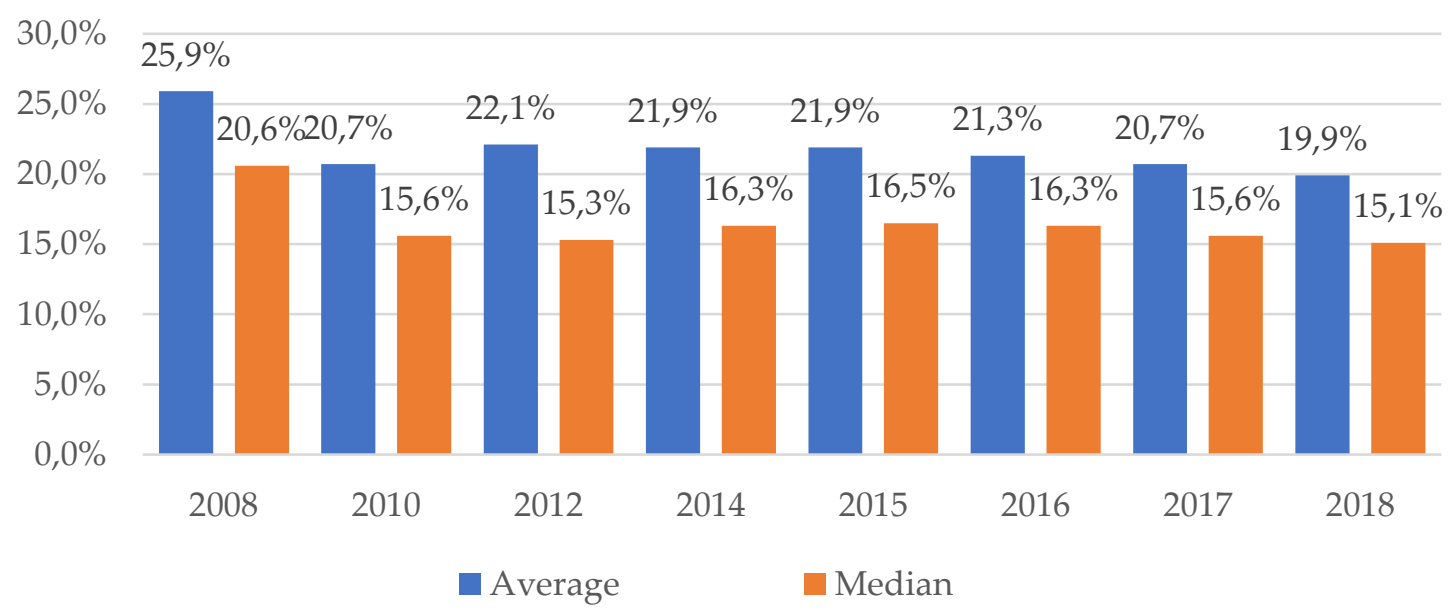

Figure 2. Gender pay gap in 2008-2018 in the Czech Republic. Own processing based on (Úřad vlády České republiky, 2018)

The gender pay gap in 2016 differs from that of Eurostat by 0.5 percentage point, yet we can see that it is significant, in spite of this inconsistency. We can clearly see that the gap in average wages diminishes by 6 percentage points but the gap in median wages oscillates between 15 and 16\%, even though it diminished in the past three years, even if only by 0.8 percentage point. As compared to 2008, this gap represents 5.5 percentage points. It is, however, a gap for the entire Czech economy. Nevertheless, our goal is to analyze the gender pay gap among ICT Professionals and its trend in the Czech Republic. For the purposes of our research, we have formulated the following research questions:

RQ1: What was the trend of the gender pay gap among ICT Professionals in the Czech Republic during 2008-2019?

RQ2: What was the trend of the gender pay gap in the two groups of ICT professions in the Czech Republic during 2008-2019?

\section{Methodology}

To answer these research questions, we used the methods that can be divided into the following three areas:

- Input research data and their collection;

- Classification of ICT professions; and

- Data analysis.

\subsection{Input Research Data and Their Collection}

The input data file that we used for our analysis comes from Trexima, a.s. that processes the AEIS (Average Earnings Information System) on a yearly basis (ISPV, 2020). The survey is harmonized with the European Union's structural survey called "The Structure of Earnings Survey" conducted based on Commission Regulation no. 1916/2000. This file contains data about earnings in the second quarter of each year because it includes the highest number of available workhours and a minimum number of national holidays and thus these earnings 
reflect the most the basic salaries of wages. The main monitored indicators in terms of earnings include gross monthly wages and hourly earnings. In addition to gross monthly wages, we also analyzed different wage components, i.e. bonuses, extra pay and reimbursements. We also analyzed the number and structure of workhours, e.g. overtime and hours not worked, e.g. sickness and vacation. The administrator of the Average Earnings Quarterly Survey is the Ministry of Labor and Social Affairs (MLSA). In our analyses, we worked with a sample of data for ICT Professionals ranging from 21,950 records in 2008 to 60,439 records in 2018.

\subsection{Classification of ICT Professions}

When analyzing wages and salaries in ICT, it is very important to divide employees into groups based on their performed work. To do so, we used the CZ-ISCO classification (CZSO, 2020a) that breaks down ICT Professionals into the following two main groups:

- ICT Specialists (CZ_ISCO 25) and

- ICT Technicians (CZ_ISCO 35).

ICT Specialists (CZ_ISCO 25) mostly perform creative work. In most cases they are creative workers with a university education - a bachelor's or a master's degree. Their work description usually includes ICT research, planning, design, complete application testing or partial program testing, consultations, improvement of IT systems, their hardware and software; processing of related documentation, including principles, policies and procedures; design, development, checking, maintenance and the support of operation of databases and other information systems to ensure optimal performance and data integrity and security (CZSO, 2020a).

ICT Technicians (CZ_ISCO 35) represent a group of professions with less creativity and this is why they usually have a high school education with technical specialization. Their work description usually includes the support of regular operation of computer and communication systems and networks, performance of technical tasks related to telecommunications and the transmission of image and sound and other types of telecommunication signals (CZSO, 2020a).

\subsection{Data Analysis}

The data from the survey on wages and salaries in the Czech Republic from 2008-2018 had to be furs adjusted for inflation - the annual inflation rates during the analyzed years are provided in Table 1. We converted the wage data to the 2008 base, using the annual inflation rate coefficients, which became the comparative base for our further analyses.

Table 1. Annual inflation rate in the Czech Republic and annual average CZK/EUR exchange rate.

Own processing based on (CZSO, 2020b; CNB, 2020)

\begin{tabular}{|c|c|c|c|c|c|c|c|c|c|c|c|c|}
\hline Item/Year & $\mathbf{2 0 0 8}$ & $\mathbf{2 0 0 9}$ & $\mathbf{2 0 1 0}$ & $\mathbf{2 0 1 1}$ & $\mathbf{2 0 1 2}$ & $\mathbf{2 0 1 3}$ & $\mathbf{2 0 1 4}$ & $\mathbf{2 0 1 5}$ & $\mathbf{2 0 1 6}$ & $\mathbf{2 0 1 7}$ & $\mathbf{2 0 1 8}$ & $\mathbf{2 0 1 9}$ \\
\hline Inflation Rate & $6.3 \%$ & $1.0 \%$ & $1.5 \%$ & $1.9 \%$ & $3.3 \%$ & $1.4 \%$ & $0.4 \%$ & $0.3 \%$ & $0.7 \%$ & $2.5 \%$ & $2.1 \%$ & $2.8 \%$ \\
\hline CZK/EUR & 24.94 & 26.45 & 25.29 & 24.59 & 25.14 & 25.97 & 27.53 & 27.28 & 27.03 & 26.33 & 25.64 & 25.67 \\
\hline
\end{tabular}


To achieve data comparability, it was also necessary to convert the wages and salaries shown in source data in Czech Crowns to EUR. For this conversion, we used average annual exchange rates that are also provided in Table 1.

We used the average of converted monthly gross wages.

The median better reflects the reality on the Czech labor market because the average is very often influenced by a very high income in the group of workers whose monthly income is over 4,000 EUR; unfortunately, we did not have the median income for the entire analyzed period. This category represents about 1.5\% of the analyzed records in 2019 and their percentage in the analyzed data goes up every year. To compare income and to identify the gender pay gap, we chose two criteria - age and education. For the comparison by age, we chose three age groups - up to 30, 30-50 and over 50. For the comparison by education, we used the following categories - high school(H_S), university - bachelor (Bc), master (Master) and doctoral (Ph.D.). We did not use elementary and vocational education because such education is not really represented in the professions of ICT Professionals.

The data adjusted for inflation and converted to EUR were then processed and analyzed, using MC Excel tools and statistical functions for analyzing time series. To approximate the trend of wages, we used the method of linear regression together with the method of least squares. In the method of linear regression, we used the general function $y=a x+b$, where $a$ represents the identified trend during the analyzed time period. All performed regression analysis calculations are at the $5 \%$ confidence level.

\section{Results \& Discussion}

The first results that we achieved in our gender pay gap research included information about how many ICT Professionals worked in the Czech economy. Figure 3 shows ICT Professionals' number and share on the number of economically active people over time.

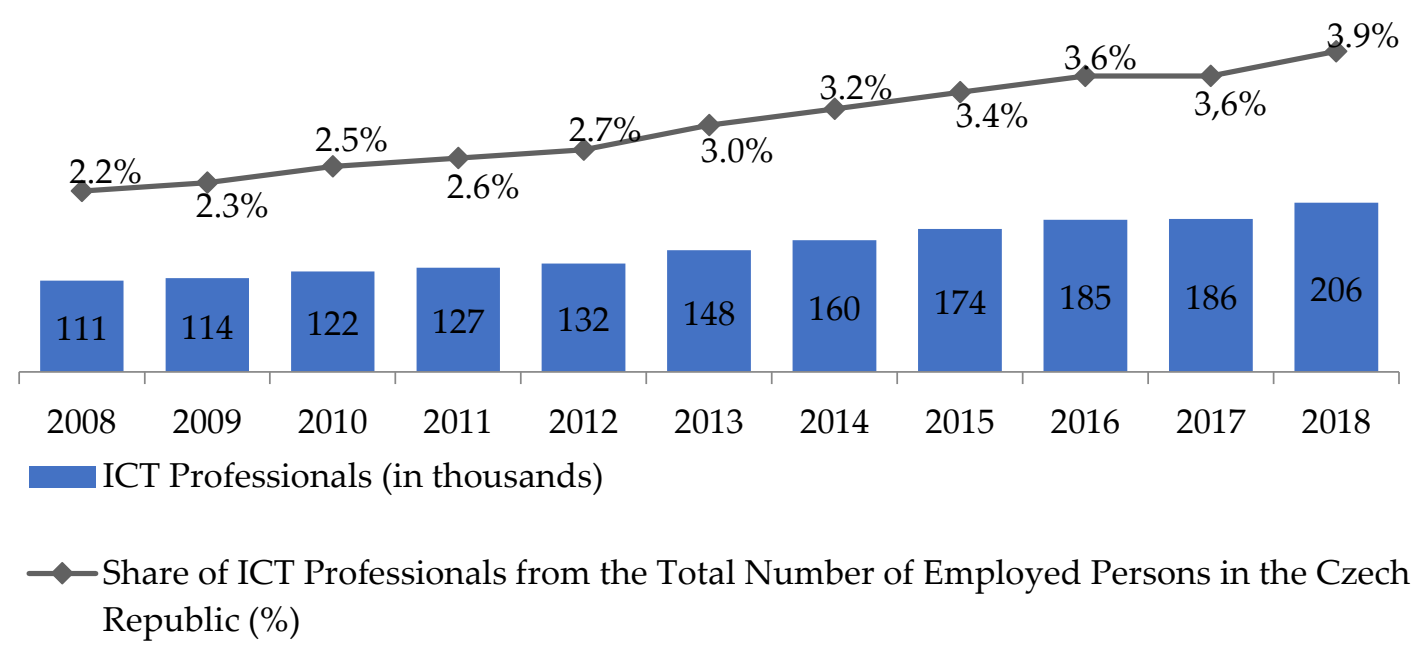

Figure 3. Ratio Between the Number of ICT Professionals and the Total Number of Workers in the Czech Republic. Own processing based on (CZSO, 2020c)

The practically constantly growing number of ICT Professionals and their share on the number of employees in the Czech economy show that the penetration of ICT into the 
economy as a whole is also growing. The goal of this article is not to find out whether or not their number is sufficient. One thing is their total number, another thing is the percentage of women in total and in individual groups of profession. The trend of these data is shown in Figure 4.

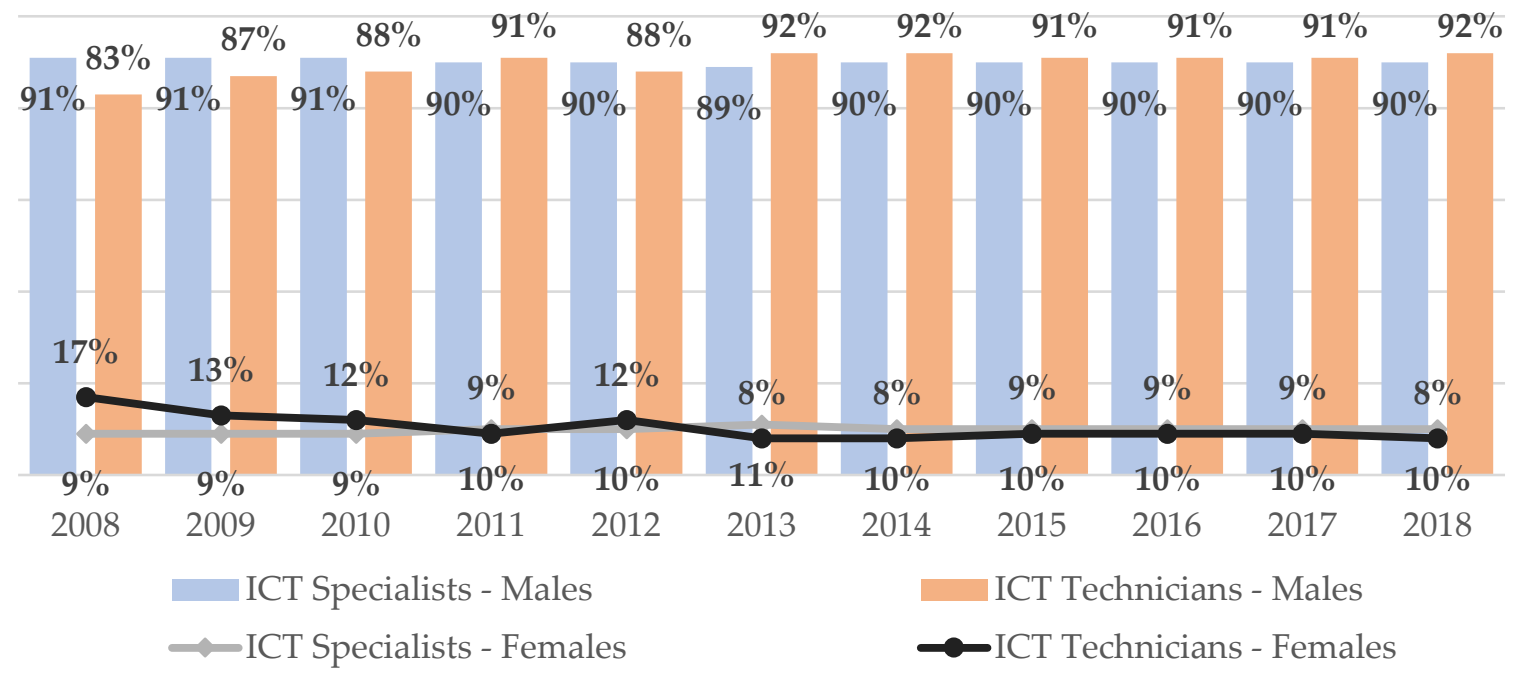

Figure 4. Ratio of Number of ICT Professionals based on the Sex and Profession authors, sources: (CZSO,2020c)

Figure 4 shows that female ICT Specialists during the analyzed time period represented $10 \%$ and female ICT Technicians $8 \%$, which is even less by two percentage points. Thus, women in the category of ICT Professionals are a significantly minority group. Their income as compared to men's income is discussed below.

The gender pay gap among ICT Professionals is provided as an aggregate characteristic in Figure 5.

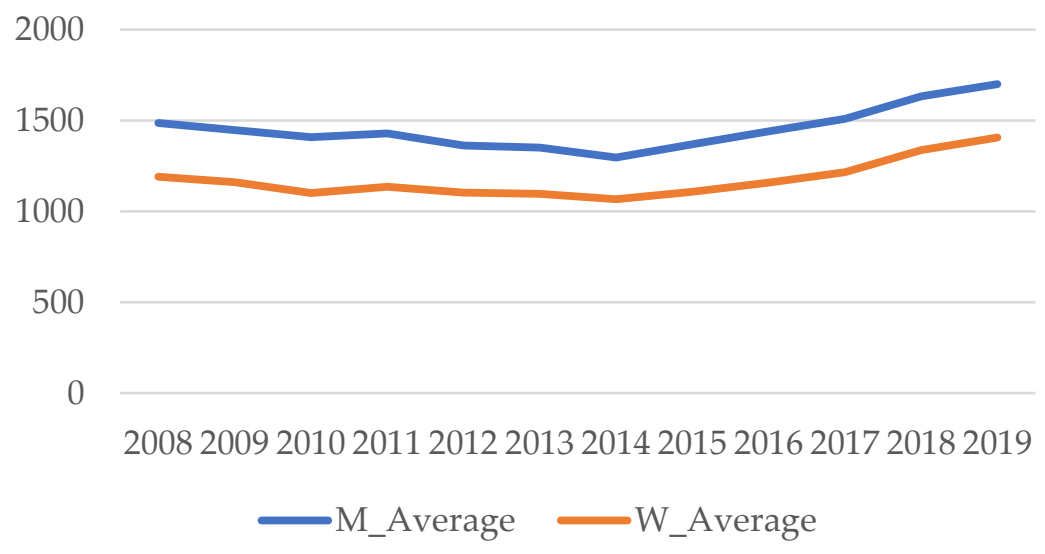

Figure 5. Income of female and male ICT Professionals - average and median. Own processing based on (Trexima, 2020)

Figure 5 clearly shows the gender pay gap because the average gross wages of women are significantly lower than the wages of men. Furthermore, it is clear from Figure 5 that the wages of ICT Professionals were permanently going up starting in 2014. The gender pay gap is shown in Figure 6. 


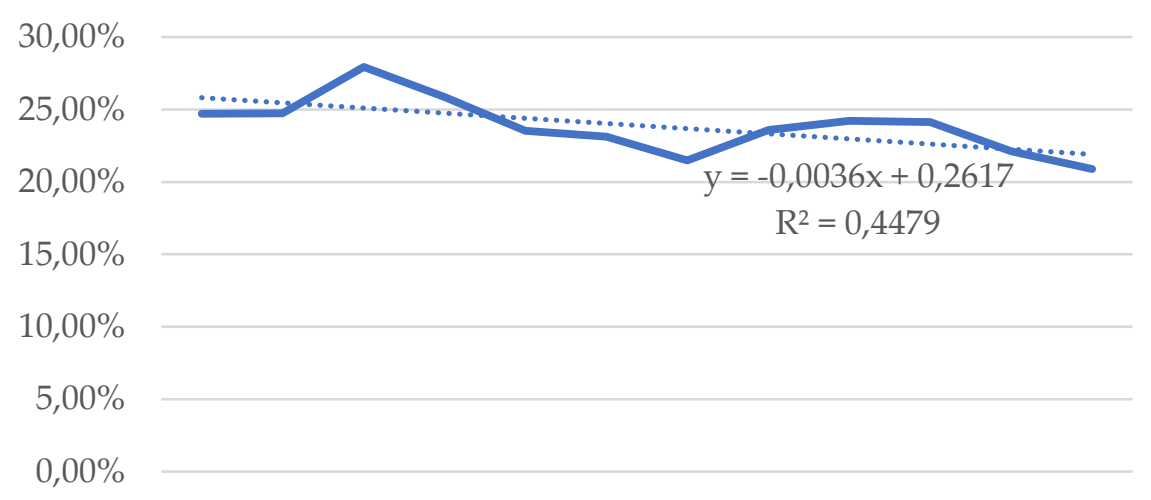

200820092010201120122013201420152016201720182019

Figure 6. Trend of the gender pay gap among ICT Professionals - average. Own processing based on (Trexima, 2020)

Figure 6 shows the percentage changes in the gender pay gap during the analyzed time period. We can see that the gap in average wages dropped from $24.70 \%$ to $20.90 \%$ - i.e. by 3.8 percentage points. The approximation of the trend of the gender pay gap using the linear function shows a very slowly decreasing trend (the slope is -0.0036 , the confidence level of the estimate is not very high, only $44.8 \%$ ). Based on this trend, the gender pay gap would disappear in approximately 72.7 years. Over the last three years, the gender pay gap has been diminishing faster.

The increase in the gender pay gap in 2010 was caused by a higher share of the business sector in the data sample.

RQ1: What was the trend of the gender pay gap among ICT Professionals in the Czech Republic during 2008-2019?

The gender pay gap among ICT Professionals shows a decreasing trend. This trend is in line with the overall policy of both the EU and the Czech Republic. However, the decreasing rate of this negative phenomenon is very small. Despite this decrease, the gender pay gap in average wages is still higher than that in the entire Czech economy, e.g. in 2018, the gender pay gap in the Czech economy was $19.9 \%$, while it was $22.12 \%$ among ICT Professionals.

\subsection{Gender Pay Gap by Age}

Age is one of the two factors that we used to analyze the gender pay gap. We will analyze it in greater depth, breaking it down to ICT Specialists and ICT Technicians.

\section{ICT Specialists - ISCO 25}

Figure 7 shows the trend of the gender pay gap among ICT Specialists.

Our findings are quite surprising. In general, the gender pay gap decreased starting in 2008 in all three categories. The biggest gender pay gap equality is among young ICT Specialists under the age of 30. The main reason is that due to the lack of ICT Specialists on the Czech market, new employees are hired under the same conditions. The decrease in this category represented a total of 9.88 percentage points during the analyzed time period! We can see a decreasing trend in the last year as well. The gender pay gap among ICT Specialists aged between 30 and 50 decreased during the analyzed time period by 6.93 percentage points. The gender pay gap among ICT Specialists over 50 decreased during the analyzed time 
period by 8.38 percentage points, although it slightly increased during the last year. The overall trend during the analyzed time period shows a decrease in the gender pay gap among ICT Specialists.

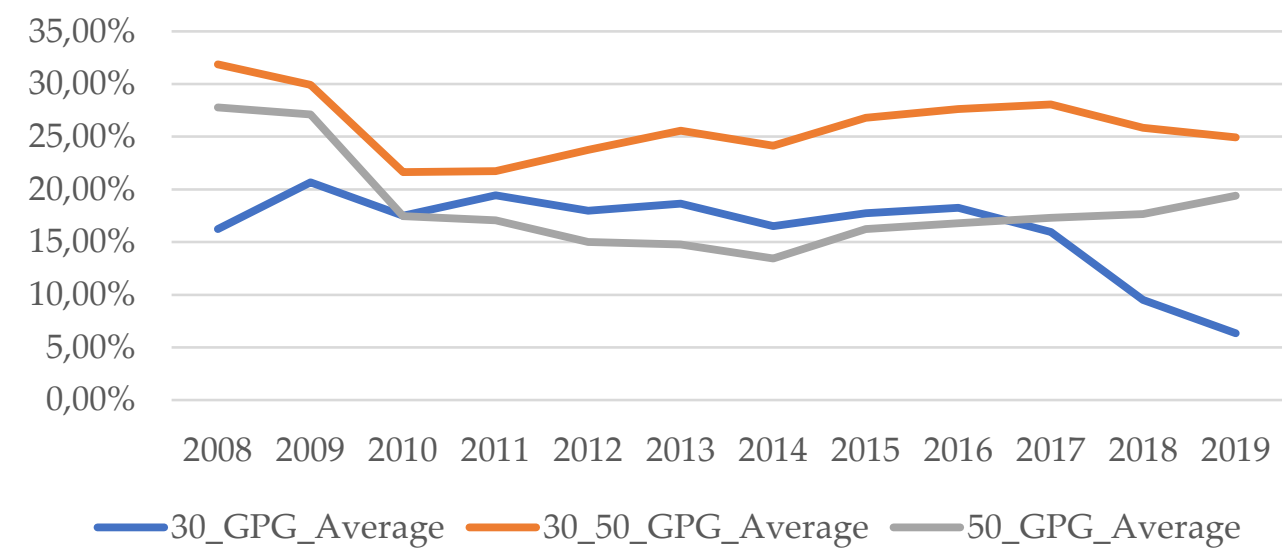

Figure 7. Trend of the gender pay gap among ICT Specialists - average wage. Own processing based on (Trexima, 2020)

\section{ICT Technicians - ISCO 35}

Figure 8 shows the trend of the gender pay gap among ICT Technicians.

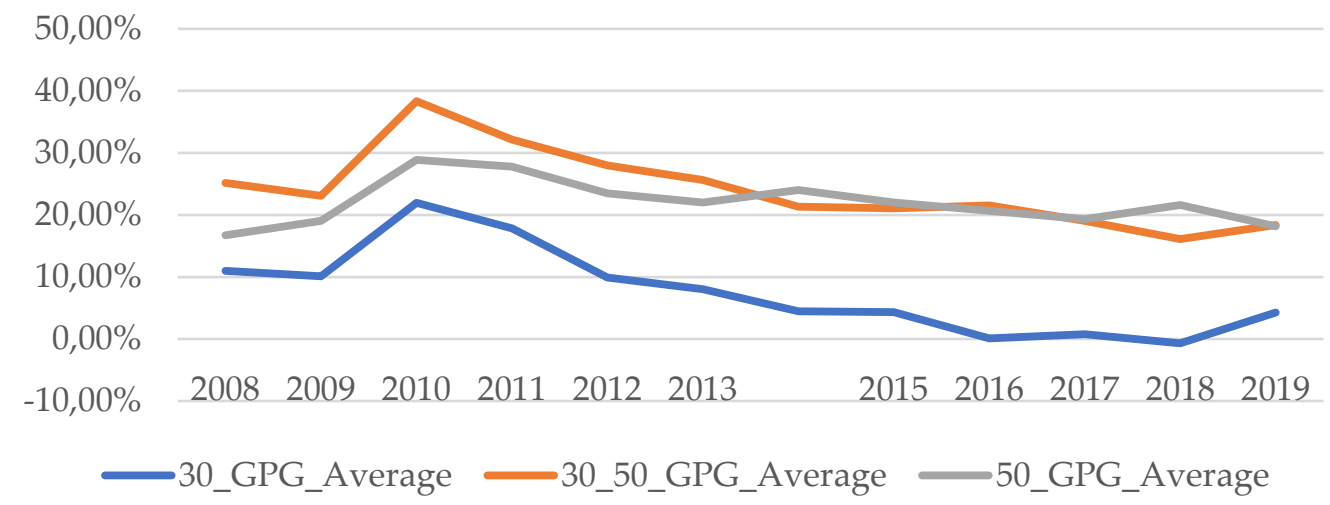

Figure 8. Trend of the gender pay gap among ICT Technicians - average wage. Own processing based on (Trexima, 2020)

The trend of the gender pay gap among ICT Technicians by age shows a decrease in two age groups. Important is mainly the decrease all the way to $0 \%$ among young ITC Technicians under 30. The increase in 2019 to $4.28 \%$ is not very significant in view of the overall trend. We can see a very similar trend in the age group between 30 and 50, where the gender pay gap during the analyzed time period decreased by 6.85 percentage points - from $25.20 \%$ to $18.38 \%$ in 2019. The only negative thing is the increase in the gender pay gap in the age group over 50 by 1.47 percentage points. Overall, ICT Technicians show a positive trend towards reducing the gender pay gap, especially in the younger age group.

\subsection{Gender Pay Gap by Education}

We also analyzed the trend of the gender pay gap in terms of achieved education. As mentioned in the methodology, we identified four levels of education for which we 
performed our data analysis. Our data analysis is interesting at first glance for two reasons. First of all, there was a minimum number of ICT Professionals with a bachelor's degree on the Czech labor market in 2008 and 2009. A large number of graduates based on the Bologna Declaration (three years of IT education to obtain a bachelor's degree and two years to obtain a master's degree) did not appear on the Czech labor market until 2010. Another interesting finding is that the number of employees with a PhD degree is so low (dozens as compared to thousands in other categories) that even a randomly selected individual can very significantly influence the average wage and thus the gender pay gap.

\section{ICT Specialists - ISCO 25}

The data are provided in Figure 9.

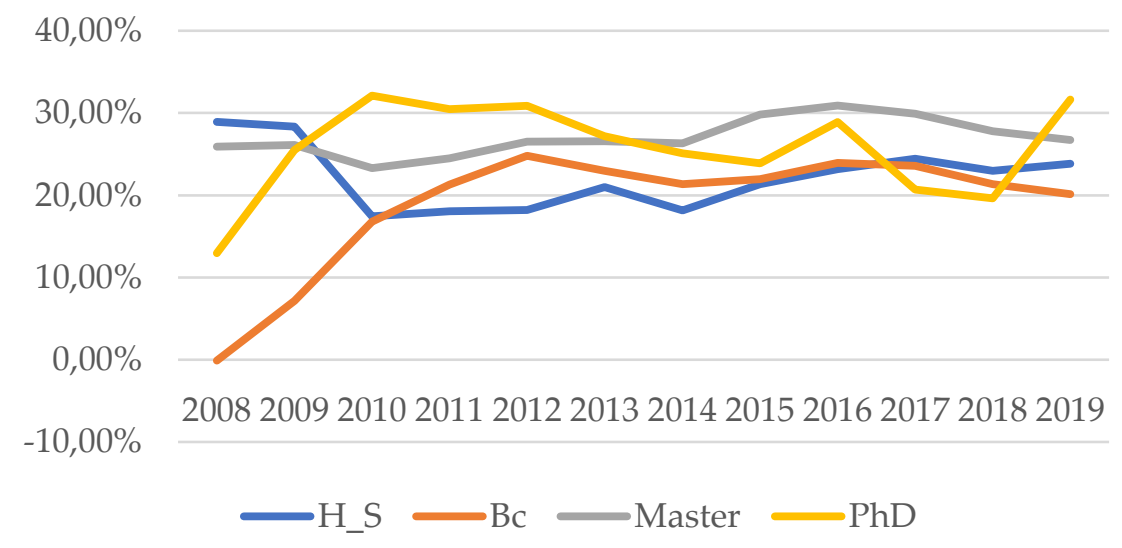

Figure 9. Trend of the gender pay gap among ICT Specialists by education - average wage. Own processing based on (Trexima, 2020)

We will mainly look at the trend of the gender pay gap among ICT Specialists with high school education, a bachelor's degree and a master's degree that our data analysis shows. ICT Specialists with high school education show a significant decrease in the gender pay gap in 2010 to $17.44 \%$. This decrease by 10.89 percentage points is a result a change in the sample, in which the number of records from the non-business sector increased at the expense of those from the business sector. Subsequently, the gender pay gap increased to $23.94 \%$ in 2019 . The gender pay gap among ICT Specialists with a bachelor's degree shows a slightly growing trend by 3.33 percentage points starting in 2010 and the gender pay gap among ICT Specialists with a master's degree shows an increase by 0.81 percentage point during the entire analyzed time period. We did not analyze the trend of the gender pay gap among ICT Specialists with a $\mathrm{PhD}$ degree due to the small amount of data.

\section{ICT Technicians - ISCO 35}

The gender pay gap among ICT Technicians is analyzed in Figure 10.

This analysis shows an increase in the gap in average wages during the analyzed time period. ICT Technicians with high school education are the only category where the gender pay gap dropped by 0.61 percentage point. ICT Technicians with a bachelor's and master's degree show the biggest gap that is about the same - approximately $25 \%$. 
We did not analyze the trend of the gender pay gap among ICT Technicians with a PhD degree due to the small amount of data.

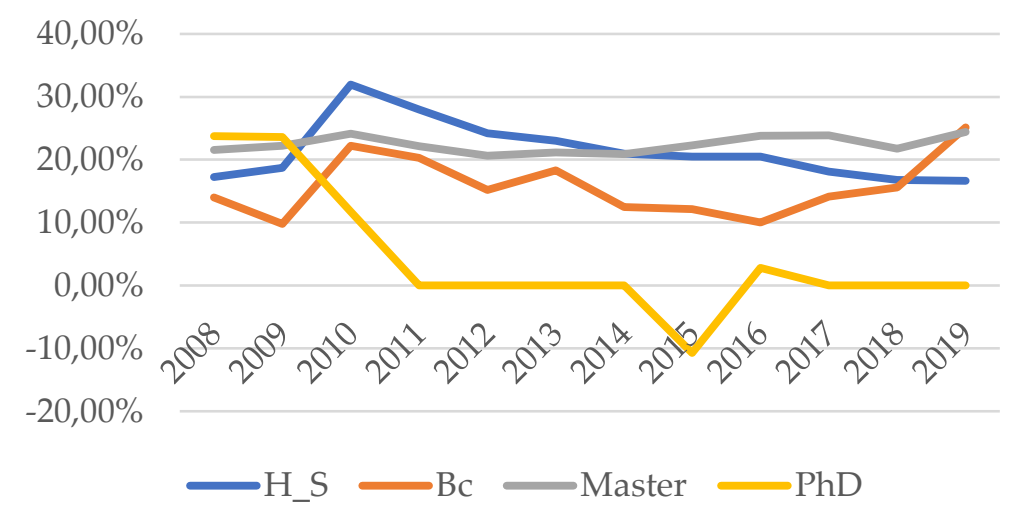

Figure 10. Trend of the gender pay gap among ICT Technicians by education - average wage. Own processing based on (Trexima, 2020)

RQ2: What was the trend of the gender pay gap in the two groups of ICT professions in the Czech Republic during 2008-2019?

Table 2 shows the result of our analysis of the gender pay gap by age.

Table 2. Gender pay gap among ICT Professionals by age. Own processing based on (Trexima,2020)

\begin{tabular}{|c|c|c|c|}
\hline & Category & ICT Specialists & ICT Technicians \\
\hline \multirow{4}{*}{ Age } & under $\mathbf{3 0}$ & $-9.88 \%$ & $-6.68 \%$ \\
\cline { 2 - 4 } & $\mathbf{3 0 - 5 0}$ & $-6.95 \%$ & $-6.85 \%$ \\
\cline { 2 - 4 } & over 50 & $-8.38 \%$ & $+1.47 \%$ \\
\hline
\end{tabular}

Our analysis by age shows a decrease in the gender pay gap practically in all categories. A very significant change is an almost non-existing gender pay gap among young, newly hired ICT Technicians, which was almost zero during 2016-2018 (it was actually negative in 2018). ICT Specialists also show the lowest gender pay gap in the age group under 30 . The overall highest gender pay gap exists in the age group between 30-50 among both ICT Specialists and ICT Technicians.

Table 3. Gender pay gap among ICT Professionals by achieved education. Own processing based on (Trexima,2020)

\begin{tabular}{|c|c|c|c|}
\hline & Category & ICT Specialists & ICT Technicians \\
\hline \multirow{4}{*}{ Education } & High school & $-5.08 \%$ & $-0.61 \%$ \\
\cline { 2 - 4 } & Bachelor's degree & $+3.23 \%$ since 2010 & $+11.13 \%$ \\
\cline { 2 - 4 } & Master's degree & $+0.81 \%$ & $+2.84 \%$ \\
\cline { 2 - 4 } & PhD & Not analyzed & Not analyzed \\
\hline
\end{tabular}

The analyzed trend of the gender pay gap by achieved education is not as unambiguous as that by age. Overall, we can say that our analysis shows a growing gap in the average wage of women and men, with the exception of those with high school education, where the gap is very slowly diminishing. ICT Specialists with a bachelor's degree show the highest increase because a bachelor's degree in ICT was not common until after 2010. Up until then, the 
number of ICT Specialists with a bachelor's degree was very small and this is why we did not analyze the years 2008 and 2009.

\section{Conclusion}

When analyzing the average wages in ICT Professionals in order to describe the trend of the gender pay gap, we identified a gradual decrease in the gap in the average gross wage of women and men - the answer to RQ1. The negative result of our analysis is that the decrease in this gap among ICT Professionals is slower than that in the entire Czech economy.

The gender pay gap among Czech ICT Professionals in terms of age and achieved education provides the answer to RQ2. The very positive finding is that the gender pay gap among young workers under the age of 30 dropped to almost zero during the analyzed time period and is about $5 \%$ in both groups of ICT Professionals.

When analyzing the data, we felt that it was necessary to expand the analyzed dimensions of the gender pay gap for the sector in which ICT Professionals work. The structure of data used for the analysis has an impact on average wages and thus on the entire gender pay gap. The percentage of records from the business sector and the non-business sector is important. We will take the impact of this dimension into account in our next research.

Another factor that could (and should in the context of the Czech Republic) have an impact on the gender pay gap is the difference between Prague or Central Bohemia and other regions, especially the border regions in the north of the Czech Republic. We could take the number of IT Specialists in individual regions into account in our analyses.

In addition, we would like to also take into account the impact of Covid-19 on the gender pay gap and to analyze the average wage of ICT Professionals in this context.

Acknowledgments: Paper was processed with support from institutional-support fund for long-term conceptual development of science and research at the Faculty of Informatics and Statistics of the University of Economics, Prague (IP400040).

\section{References}

Bergmann, N., Scheele, A., \& Sorger, C. (2018). Variations of the same? A sectoral analysis of the gender pay gap in Germany and Austria. Gender, Work E Organization, 26(5), pp. 668-687. https://doi.org/10.1111/gwao.12299

Bílková, D. (2017). Vývoj genderové mzdové nerovnosti v České republice za posledních 20 let. Politická ekonomie, 65(5), 623-646. https://doi.org/10.18267/j.polek.1167

Boll, C., \& Lagemann, A. (2019). The Gender Pay Gap in EU Countries - New Evidence Based on EU-SES 2014 Data. Intereconomics, 54(2), 101-105. https://doi.org/10.1007/s10272-019-0802-7

Cohen, M., \& Kiran, T. (2020). Closing the Gender Pay gap in Canadian Medicine. Canadian Medical Association Journal, 192(35), E1011-E1017. https://doi.org/10.1503/cmaj.200375

Duffin, E. (2020). Female to male earnings ratio of workers in the United States from 1990 to 2019. https://www.statista.com/statistics/203459/female-to-male-earnings-ratio-of-workers-in-the-us/

CNB Česká národní banka. (2020). Kurzy devizového trhu. https://www.cnb.cz/cs/financni-trhy/devizovytrh/kurzy-devizoveho-trhu/kurzy-devizoveho-trhu/prumerne_mena.html?mena=EUR

CZSO Český statistický úřad. (2020a). Klasifikace zaměstnání (CZ-ISCO). https://www.czso.cz/csu/czso/ klasifikace_zamestnani_-cz_isco-

CZSO Český statistický úřad. (2020b). Inflace - druhy, definice, tabulky. https://www.czso.cz/csu/czso/ mira_inflace 
CZSO Český statistický úřad. (2020c). IT odborníci. https://www.czso.cz/csu/czso/ict-odbornici

Eurostat. (2020). Gender pay gap statistics. https://ec.europa.eu/eurostat/statistics-explained/index.php/ Gender_pay_gap_statistics

Forman, M. (2019). Gender Pay Gap in the State Administration of the Czech Republic. In O. Dvouletý, M. Lukeš, \& J. Mísař (Eds.), Proceedings of the 7th International Conference Innovation Management, Entrepreneurship and Sustainability (IMES 2019) (pp. 208-219). Prague University of Economics and Business. https://imes.vse.cz/wp-content/uploads/2019/07/Conference_Proceedings_IMES_2019.pdf

Ganguli, I., Sheridam, B., Gray J., Chernew, M., Rosehthal, M. B., \& Nerpash, H. (2020). Physican Work Hours and the gender Pay Gap -Evidence for Pirmary Care. New England Journal of Medicine, 383(14), 1349-1357. https://doi.org/10.1056/NEJMsa2013804

Gomolka, A. (2018). Gender Pay Gap in the ICT Sector in Poland in 2010-2016. In R. Veselica, G. Dukic, \& K. Hammes (Eds.), Proceedings of the 36th International Scientific Conference on Economic and Social Development (ESD) - Building Resilient (pp. 813-822). Varazdin Development \& Entrepreneurship Agency. https://www.esd-conference.com/upload/book_of_proceedings/Book_of_Proceedings_esdZagreb2018_ Online.pdf

ISPV. (2020). Informační systém o průměrném výdělku. https://www.ispv.cz/

Landmesser, J., Orłowski, A. J., \& Rusek, M. A. (2020). Gender Pay Gap Across the Income Distribution: Analysis for the EU. Acta Physica Polonica, A.138, 31-40. https://doi.org/10.12693/APhysPolA.138.31

Maldonado, L. (2020). Decomposing the gender pay gap in the formal sector in Venezuela: a microdata analysis 1985-2015. Applied Economics Letters, 1-8. https://doi.org/10.1080/13504851.2020.1784830

Marek, L., \& Doucek, P. (2016). Vývoj mezd a příjmové nerovnosti u ICT odborníků v České republice. Politická ekonomie, 64(8), 922-938. https://doi.org/10.18267/j.polek.1118

Marek, L., \& Doucek, P. (2018). The Wages of Male and Female ICT Managers in the Czech Republic and the Slovak Republic. In K. S. Soliman (Ed.), Proceedings of the 32nd Conference of the International-BusinessInformation-Management-Association (IBIMA) - Vision 2020: Sustainable Economic Development and Application of Innovation Management from Regional expansion to Global Growth (pp. 3525-3533). Int. Business Information Management Assoc-IBIMA. https://ibima.org/accepted-paper/the-wages-of-male-and-female-ict-managersin-the-czech-republic-and-the-slovak-republic/

Marek, L., Doucek, P., \& Nedomová, L. (2018). Development of ICT Professional Wages in Czech Republic. In P. Doucek, G. Chroust, \& V. Oškrdal (Eds.), Proceedings of the 26th Interdisciplinary Information Management Talks - IDIMT-2018 Strategic Modeling in Management, Economy and Society (pp. 49-56). Trauner Verlag Universität. https://idimt.org/wp-content/uploads/proceedings/IDIMT_proceedings_2018.pdf

Mitková, L. (2018). Occupational Segregation and Gender Pay Gap in Slovakia. In K. S. Soliman (Ed.), Proceedings of the 31st International Business Information Management Association Conference (IBIMA) Innovation Management and Education Excellence Through Vision 2020 (pp. 5023-5030). Int. Business Information Management Assoc-IBIMA. https://ibima.org/accepted-paper/occupational-segregation-andgender-pay-gap-in-slovakia/

Nedomova, L., \& Doucek, P. (2015). Gender Aspects in ICT. In C. Niculescu, O. D. Negoita, \& B. Tiganoaia (Eds.), Proceedings of the 7th International conference of management and industrial engineering - Management - Key Driver for Creating Value (pp. 508-516). University Politehnica Bucharest.

Nedomova, L., Maryska, M., \& Doucek, P. (2017). Unequal wage of men and women in ICT in the Czech Republic? Gender, Technology and Development, 21(1-2), 116-134. https://doi.org/10.1080/ 09718524.2017.1385317.

Peters, E., Drobe, J., \& Abendroth, A. (2020). Equality Through Equal Opportunity Policies? Workplace Mentoring Programs, Female Quotas, and the Gender Pa Gap within German Workplaces. Kolner Zeitschrift fur Soziologie und Sozialpsychologie, 72(2), 225-263. https://doi.org/10.1007/s11577-020-00695-y

Úřad vlády České republiky. (2018). Zpráva za rok 2018 o rovnosti žen a mužů. https://www.vlada.cz/assets/ ppov/rovne-prilezitosti-zen-a-muzu/dokumenty/Material---Zprava-za-rok-2018-o-rovnosti_FINAL.pdf

Vltavská, K., Mazouch, P., Juř́ková, K., \& Lorencová, Š. (2019). Gender Pay Gap among University Students and Graduates: The Comparison of the Expectations and the Reality. In J. Fejfar, M. Fejfarova, M. Flegl, \& I. Krejčí (Eds.), Efficiency and Responsibility in Education 2019 (ERIE) (pp. 310-315). Czech University of Life Sciences Prague. https://erie.v2.czu.cz/en/r-14822-proceedings-2019

Whitehouse, G., \& Smith, M. (2020). Equal pay for work of equal value, wage-setting and the gender pay gap. Journal of Industrial Relations, 62(4), 519-532. https://doi.org/10.1177/0022185620943626 